\title{
SPECT/CT によるラット嗅神経の画像評価
}

\author{
${ }^{1)}$ 金沢医科大学医学部感覚機能病態学 (耳鼻咽喉科学) \\ 2)金沢大学大学院医学系研究科量子医療技術学講座 \\ 3)金沢大学大学院自然科学研究科薬学系臨床分析科学講座 \\ 4)浜松医科大学分子イメージング先端研究センター動物イメージング研究部門 \\ ${ }^{55}$ 浜松医科大学光量子医学研究センターゲノムバイオフォトニクス研究分野 \\ 6)金沢大学 \\ 志賀 英 明 $^{1)}$, 鷲山幸 信 $^{2}$, 小川 数 馬 ${ }^{3)}$ \\ 山口 博 司 ${ }^{4}$, 間賀田 泰寛 ${ }^{4,5}$, 天野 良 平 ${ }^{2}$ \\ 古川 俩 ${ }^{6)}$, 三 輪 高 喜 $^{1)}$
}

\section{Olfactory Nerve Imaging with SPECT/CT in Rats}

\author{
Hideaki Shiga $^{1)}$, Kohshin Washiyama ${ }^{2)}$, Kazuma Ogawa ${ }^{3)}$, \\ Hiroshi Yamaguchi' ${ }^{4)}$, Yasuhiro Magata ${ }^{4,5)}$, Ryohei Amano ${ }^{2)}$, \\ Mitsuru Furukawa ${ }^{6}$, Takaki Miwa ${ }^{1)}$ \\ ${ }^{1)}$ Department of Otorhinolaryngology, Head and Neck Surgery, \\ Kanazawa Medical University, Ishikawa, Japan \\ ${ }^{2)}$ Department of Quantum Medical Technology, Graduate School of Medical Science, \\ Kanazawa University, Kanazawa, Japan \\ ${ }^{3}$ Department of Clinical and Analytical Sciences, School of Pharmaceutical Sciences, \\ College of Medical, Pharmaceutical and Health Sciences, Kanazawa University \\ ${ }^{4)}$ Division of Animal Imaging, Molecular Imaging Frontier Research Center, \\ Hamamatsu University School of Medicine, Hamamatsu, Japan \\ ${ }^{5}$ Laboratory of Genome Biophotonics, Photon Medical Research Center, \\ Hamamatsu University School of Medicine, Hamamatsu, Japan \\ ${ }^{6}$ Kanazawa University, Kanazawa, Japan
}

Objective : To image the olfactory nerve in vivo using single-photon emission computed tomography (SPECT) and X-ray computed tomography (CT) after nasal thallium-201 $\left({ }^{201} \mathrm{Tl}\right)$ administration to rats.

Methods: Three 8-week-old female Wistar rats (Japan SLC, Shizuoka, Japan) used in this study were assessed under anesthesia (intraperitoneal administration of pentobarbital sodium; $0.05 \mathrm{mg} / \mathrm{g}$ body weight) for ${ }^{201} \mathrm{Tl}$ transport to the olfactory bulb $8 \mathrm{~h}$ after nasal administration of ${ }^{201} \mathrm{TlCl}$ solution $(50 \mu 1,74 \mathrm{MBq} / \mathrm{ml}$, Nihon Medi-Physics, Tokyo, Japan) using SPECT/CT (Flex X-SPECT, Gamma Medica-Ideas, USA). The heads of rats were assessed for autoradiography to confirm ${ }^{201} \mathrm{Tl}$ transport to the olfactory bulb after SPECT/CT.

Results : ${ }^{201} \mathrm{Tl}$ transport to the olfactory bulb was shown using SPECT/CT $8 \mathrm{~h}$ after nasal administration of ${ }^{201} \mathrm{Tl}$. Coronal section imaging especially indicated ${ }^{201} \mathrm{Tl}$ transport from the nasal cavity to the olfactory bulb. ${ }^{201} \mathrm{Tl}$

(2009年 3 月 24 日受稿, 2009 年 7 月 1 日受理)

連絡先, 別冊請求先 : 志賀 英明 $\overline{7} 920-0293$ 石川県河北郡内灘町大学 1-1 金沢医科大学医学部感覚機能病態学

(耳鼻咽喉科学) TEL : 076-218-8146 FAX : 076-286-5566 E-mail : shigah@kanazawa-med.ac.jp 
志賀 論 文 付図 (1)

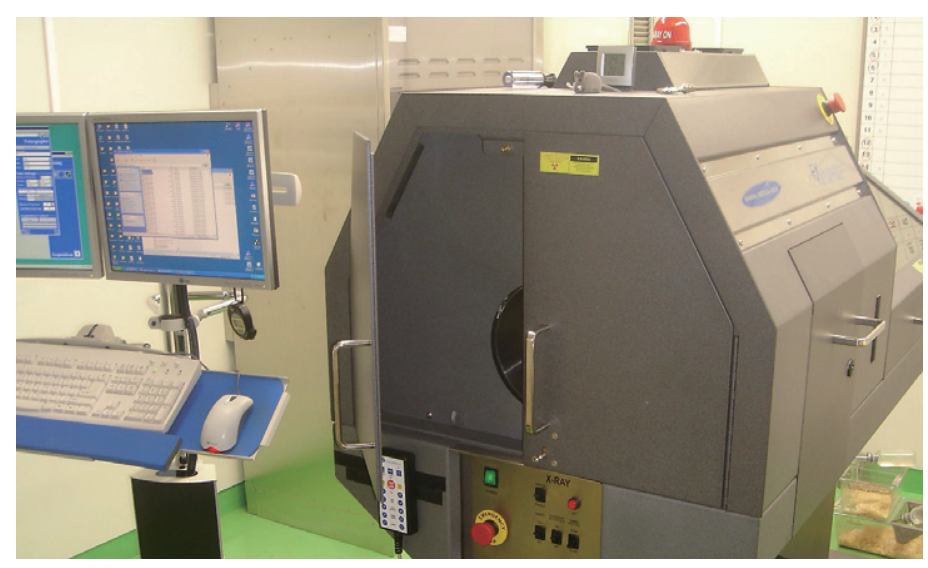

図 1 動物用 SPECT/CT 装置（浜松医科大学設置） Flex X-SPECT, Gamma Medica-Ideas (USA)

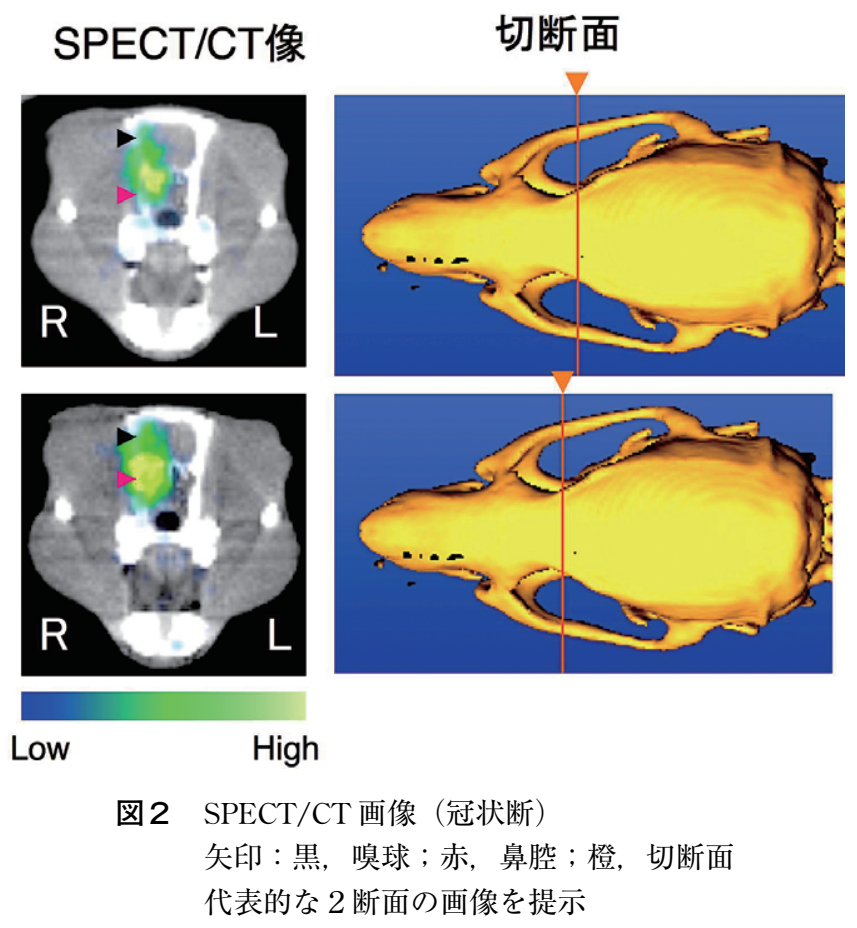


志 賀 論 文 付 図 (2)

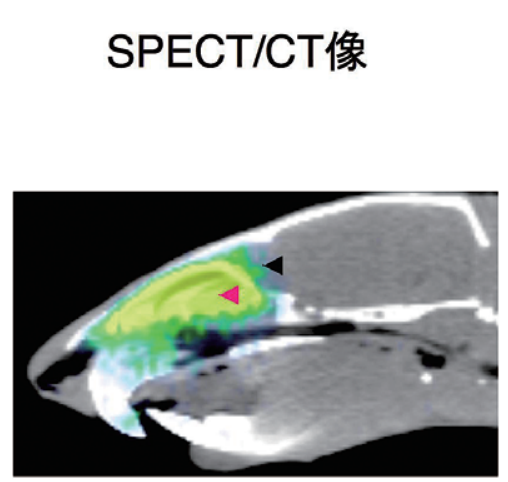

切断面
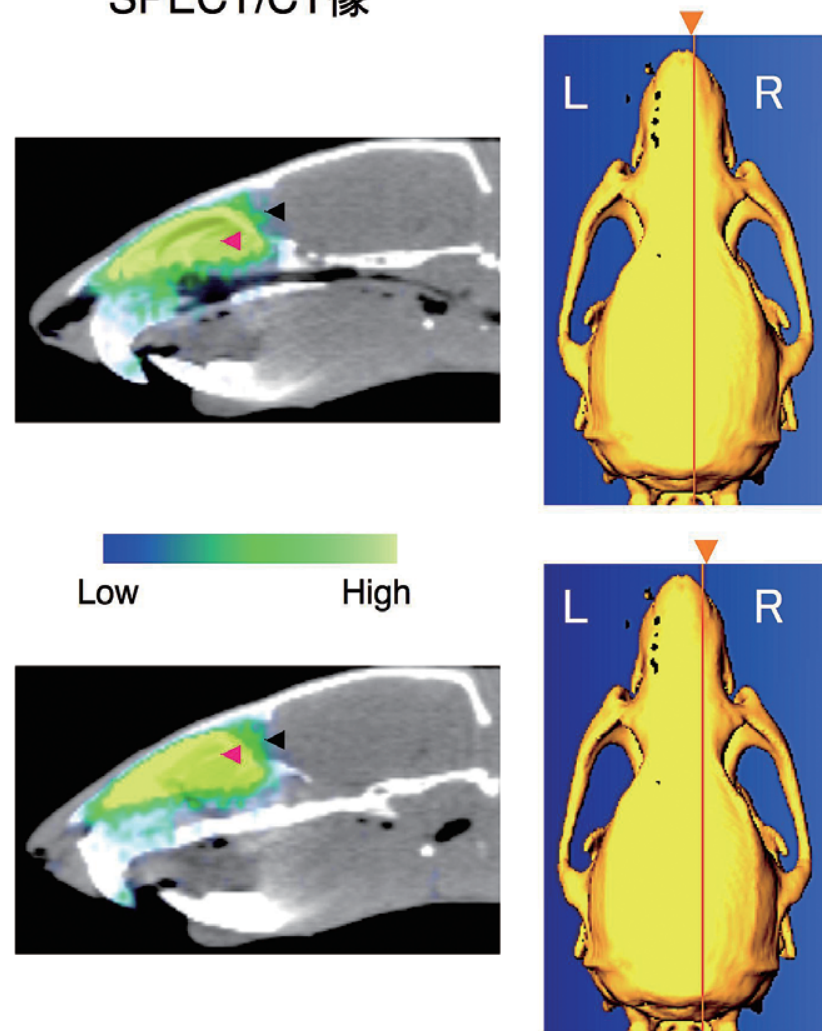

図3 SPECT/CT 画像（矢状断）

矢印：黑, 嗅球; 赤, 鼻沿; 橙, 切断面 代表的な 2 断面の画像を提示

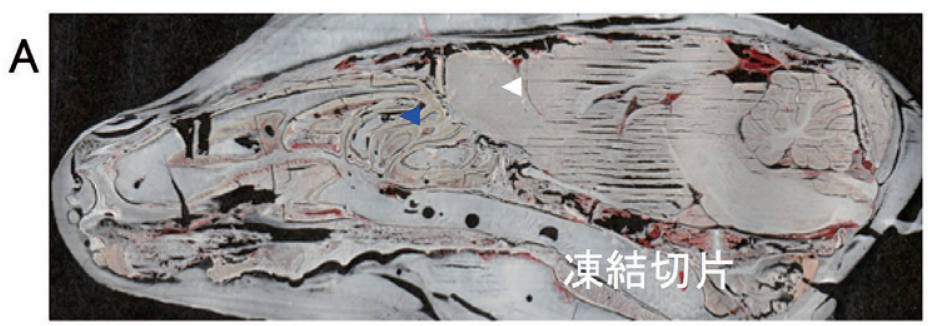

B

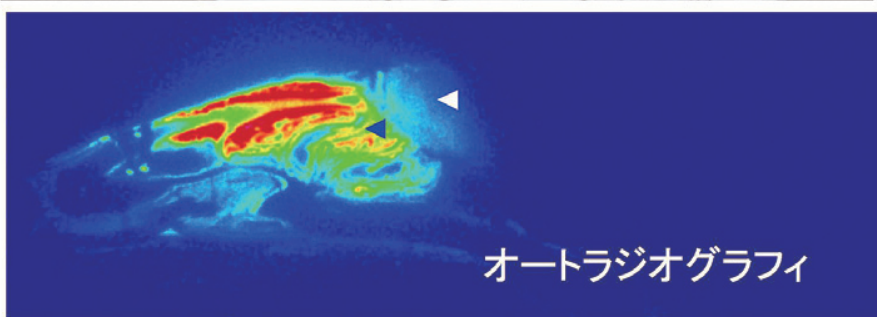

C

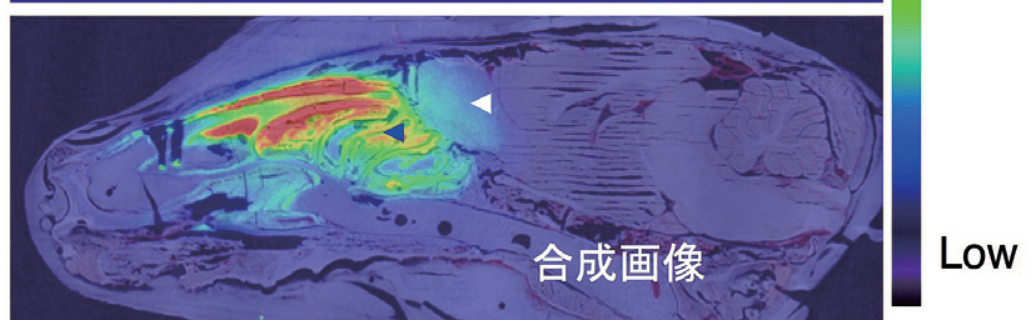

図4 (A) 凍結切片, (B) オートラジオグラフィ, (C) 合成画像 矢印：白, 嗅球; 青, 鼻腔 
transport to the olfactory bulb was confirmed by autoradiography.

Conclusion: SPECT/CT showing ${ }^{201} \mathrm{Tl}$ transport to the olfactory bulb may be useful in visually assessing the olfactory nerve in vivo.

Key words : 嗅神経, SPECT/CT, タリウム, 分子イメージング, 経鼻投与, 冠状断

olfactory nerve, SPECT/CT, thallium, molecular imaging, nasal administration, coronal section

\section{はじめに}

我が国の標準的な嗅覚障害の検査法として T \& T オ ルファクトメータ ル $^{1)}$ と, 静脈性嗅覚検査 ${ }^{2)}$ が存在するが, いずれも被験者の自覚的反応にもとづいた診断法であ る。一方で代表的な他覚的嗅覚検査法としてこれまでニ オイ刺激時の脳波計測, fMRI, PET, 脳磁図などいく つかの試みがなされているが未だ研究段階にある3”。こ れらの検査はいずれも脳神経中枢における変化を測定す る技術であるため，嗅粘膜や嗅神経末梢部位の障害の直 接的評価は困難である。臨床において嗅神経の直接の画 像化に成功した例はなく，嗅覚障害の原因として頻度の 高い，鼻副鼻胿炎，感冒扔よび頭部外傷に伴う末梢神経 性嗅覚障害の原因部位の診断は困難であった4)。

新たな他覚的嗅覚検查法の開発のため, これまで我々 は動物実験 ${ }^{5-7)} に よ り$ 明らかとなった経鼻投与後の, 放 射性アイソトープ, タリウム-201 $\left.{ }^{201} \mathrm{Tl}\right)$ の嗅神経移行 性に着目し， ${ }^{201} \mathrm{Tl}$ をバイオトレーサーとしたガンマカメ ラとX線像による生体内嗅神経イメージングの可能性に ついて明らかにしてきた8。

本研究においては, ガンマカメラを対象物の周囲で回 転させ 3 次元情報を取得でき，より詳細な画像を再構成 可能な Single photon emission computed tomography (SPECT) と X 線 CT の複合機（SPECT/CT）を用いた 生体内嗅神経イメージングを, ${ }^{201} \mathrm{Tl}$ 経鼻投与後のラット を対象に行った。その後, ラット頭部を解剖し凍結切片 に対するオートラジオグラフィにより，ラット嗅球組織 中の ${ }^{201} \mathrm{Tl}$ 集積を確認した。経鼻投与後の ${ }^{201} \mathrm{Tl}$ の嗅球への 移行像を SPECT/CTにより明瞭に描出可能であったの でここに報告する。

\section{対象と方法}

\section{${ }^{201} \mathrm{Tl}$ 嗅神経イメージング（SPECT/CT）}

ネンブタール麻酔下 $(0.05 \mathrm{mg} / \mathrm{g}$ body weight $) に$, 背臥位としたWistar ラット（3匹；8W，Female，日本 SLC, 静岡）の右外鼻孔より, $50 \mu 1$ の塩化タリウム

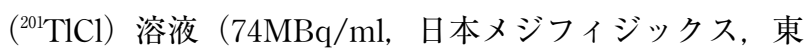

京）を, マイクロピペットで鼻腔内へ滴下した。 ${ }^{201} \mathrm{TlCl}$ 溶液投与 8 時間後, 再びネンブタール麻酔下 $(0.05 \mathrm{mg} / \mathrm{g}$ body weight）にSPECT/CT（図 1 : Flex X-SPECT, Gamma Medica-Ideas, USA）を施行した。SPECT 撮影 には 1 時間を要した。CT 画像は冠状断と矢状断を構成 し検討した。以前の我々の報告8 を参考として, SPECT/ $\mathrm{CT}$ 撮影はラットの嗅球への ${ }^{201} \mathrm{Tl}$ 移行が最も明らかに描 出可能である, 投与 8 時間後にのみ施行した。

オートラジオグラフィ

SPECT/CT 終了後, いったん室温でラット頭部を解 剖し, 皮䖉や筋肉など頭部表面の軟部組織を除去した。 その後, $-20^{\circ} \mathrm{C} に$ にいて基郕（Tissue-Tek OCT Compound, サクラ精機, 東京）に包埋した後にミクロトー ム（5030 Cryostat, Bright Instrument, England）を用い て, 投与側（右）の鼻腔と嗅球を主に含む $50 \mu \mathrm{m}$ 厚の凍 結切片（矢状断）を作成した。凍結切片作成の際には, ラットでは嗅球と脳組織が鼻腔の後方に位置するため, 頭部全体における ${ }^{201} \mathrm{Tl}$ 集積分布の確認に優れた矢状断 を用いた。イメージングプレート（BAS-SR2025，富士 フィルム, 東京）に標本を感光させ, フルオロ・イメー ジアナライザー(FLA-3000, 富士フィルム, 東京)で ${ }^{201} \mathrm{Tl}$ の集積を画像化した。

本研究の遂行にあたっては, 金沢大学動物実験委員会 の承認を得た。

\section{結果}

\section{SPECT/CT 画像（冠状断）}

${ }^{201} \mathrm{TlCl}$ 溶液投与の 8 時間後の SPECT/CT 冠状断像の 各スライスでは，投与側（右）の鼻腔および嗅球部にお いて ${ }^{201} \mathrm{Tl}$ の集積を認めた（図 2 ; 右側のイメージが SPECT/CT 画像，左側のイメージが切断面の箇所を示 す立体画像)。対側（左）の鼻䏶と嗅球部には ${ }^{201} \mathrm{Tl}$ 集積 のアーチファクトは認めなかった。冠状断では筛板を境 界として鼻腔と嗅球部の位置の同定が容易であり, 鼻腔 から嗅球への ${ }^{201} \mathrm{Tl}$ 移行が明らかに示された。

SPECT/CT 画像（矢状断）

${ }^{201} \mathrm{TlCl}$ 溶液投与の 8 時間後の SPECT/CT 矢状断像で 
も，投与側（右）の鼻腔および嗅球部において ${ }^{201} \mathrm{~T} 1$ の 集積を認めた（図 3 ; 右側のイメージが SPECT/CT 画 像, 左側のイメージが切断面の箇所を示す立体画像)。 鼻胿における ${ }^{201} \mathrm{Tl}$ 集積分布の検討には矢状断像は優れ るが, SPECT/CTでは冠状断と比較して穊板と嗅球の 描出が明暸ではないため, 鼻腔から嗅球への ${ }^{201} \mathrm{Tl}$ 移行 が判定しにくいと思われた。

$$
\text { オートラジオグラフィ }
$$

${ }^{201} \mathrm{TlCl}$ 溶液投与後の鼻胿から嗅球への ${ }^{201} \mathrm{Tl}$ 移行を確認 するため, SPECT/CT 終了後にラット頭部を解剖して オートラジオグラフィを施行した。投与側（右）鼻腔に おいて ${ }^{201} \mathrm{Tl}$ 集積を最も著明に認めたが，嗅球において も ${ }^{201} \mathrm{Tl}$ 集積を認めた（図 4)。以上の結果より, SPECT/ CT 画像に扔いて描出された鼻腔から嗅球への ${ }^{201} \mathrm{Tl}$ 移行 像は，実際の組織に扔ける ${ }^{201} \mathrm{Tl}$ 集積分布を反映してい ると考えられた。

\section{考察}

本研究に扔いて ${ }^{201} \mathrm{Tl}$ をバイオトレーサーとした SPECT/CT 装置による, 新たな生体内嗅神経イメージ ングの可能性が明らかとなった。SPECT/CT では 3 次 元的にデー夕を収集し, 冠状断像を容易に再構成できる ため, 笁板を境界とした鼻腔から嗅球への ${ }^{201} \mathrm{Tl}$ 移行を 明瞭に描出することが可能と思われた。本研究を契機と して, SPECT/CTが臨床試験において有用な画像検査 である可能性が示唆された。

放射性アイソトープを用いた嗅神経イメージングとし て，マンガンの鼻腔投与と MRIを用いた方法が動物実 験で報告されているが9), 動物実験や人体においてマン ガンの鼻腔からの吸入が神経毒性をもたらすことが明ら かとなっている ${ }^{10}$ 。従ってマンガンの経鼻投与による画 像検査法はいまだに臨床応用には至っていない。対し て, 塩化タリウム $\left.{ }^{(201} \mathrm{TlCl}\right)$ は経静脈的投与では人体に 対する安全性が確立された薬剤である ${ }^{11,122}$ 。さらに我々 はこれまで ${ }^{201} \mathrm{TlCl}$ を経鼻投与した際の化学的毒性や放 射線による生物学的影響を動物実験で検討したが，嗅覚 や嗅粘膜及び消化管粘膜には障害を生じないことを明ら かとしている ${ }^{13)}$ 。

${ }^{201} \mathrm{Tl}$ が嗅神経細胞に取り达まれる機序について は, ${ }^{201} \mathrm{Tl}$ が溶液中では一価の陽イオン $\left(\mathrm{Tl}^{+}\right)$として存 在し, このイオンがアルカリ金属イオンと同じ一価の陽 イオンであることやイオン半径が類似していることか ら， $\mathrm{K}^{+}$イオンに類似の動態を取ることが予想され ${ }^{14)}$, 嗅上皮粘膜に吸収された $\mathrm{Tl}^{+}$イオンが嗅覚受容体細胞の 膜表面のイオンチャネルを介して取り込まれ，嗅神経に
移行しているのではないかと推測されるが，詳細は明ら かではなく今後の検討課題である。さらに ${ }^{201} \mathrm{Tl}$ 経鼻投 与後のマウス脳組織における ${ }^{201} \mathrm{Tl}$ 集積を検討した以前 の報告 ${ }^{5)}$ では, 嗅球より中枢の脳神経領域への ${ }^{201} \mathrm{Tl}$ 移行 は少なく，時間経過とともに急速に減衰してしまうこと が明らかとなっており, 本研究でラット嗅球に描出され た ${ }^{201} \mathrm{Tl}$ 集積像は嗅神経の軸索終末に位置する可能性が 示唆される。従って, ${ }^{201} \mathrm{~T} 1$ 経鼻投与と SPECT/CTを用 いた嗅神経イメージングは, 嗅神経末梢領域の画像診断 に特に優れた検查方法と考えられ， ${ }^{201} \mathrm{Tl}$ 経鼻投与後長時 間経過した後でも ${ }^{201} \mathrm{~T} 1$ の嗅球より中枢領域への移行の 検出は困難であることが予想される。また, 神経活動が 活発化した際の, $\mathrm{Tl}^{+}$イオンの嗅神経移行の促進の可能 性も残されており, ${ }^{201} \mathrm{Tl}$ の嗅神経移行像が嗅神経の連続 性を反映しているのみならず，嗅覚自体を表しているこ とも考元られる。

今後臨床応用を志向するにあたり問題点は, ヒトの嗅 球，嗅神経がラットと比較し，大脳に対する比率が極め て低い点があげられる。従って ${ }^{201} \mathrm{Tl} の$ 嗅球移行が人体 においても SPECT/CT のみで検出可能であるかは明ら かではない。脳神経組織の描出に優れる MRI 画像との Fusion 画像の構築が詳細な位置情報の把握に有用であ る可能性が考えられ, 今後の検討課題である。今後我々 は, 正常被験者および嗅覚障害者を対象に, SPECT/CT を用いた ${ }^{201} \mathrm{TlCl}$ の経鼻投与による嗅神経イメージング の安全性と有用性を検討する臨床試験を計画している。

\section{謝辞}

技術協力を給わりました金沢大学附属病院アイソトー プ部に感謝します。本論文の要旨の一部は, 第47回日本 鼻科学会（2008年 9 月 25 日～27日, 名古屋市) において 発表した。

\section{参考文献}

1) Takagi SF : A standard olfactometer in Japan. A view over ten years. Ann NY Acad Sci 1987; 510 : 113-8.

2 ) 調所寛之: 静脈性嗅覚検査（アリナミンテスト). 耳鼻咽喉科プラクティス 12 一嗅覚・味覚障害の臨床 最前線一 (池田勝久, 加我君孝編), 文光堂, 東京, 2003, pp20-3.

3 ) 三輪高喜, 志賀英明, 塚谷才明, 他 : 嗅覚研究 - 臨 床の進歩一嗅覚検査の現状と展開一. 日耳鼻 $2008 ; 111: 399-404$.

4) 三輪高喜：嗅覚障害の病因・病態.脳21 2006; 


$$
9: 156-61 .
$$

5 ) Kanayama $\mathrm{Y}$, Enomoto $\mathrm{S}$, Irie $\mathrm{T}$, et al : Axonal transport of rubidium and thallium in the olfactory nerve of mice. Nucl Med Biol 2005 ; 32 : 505-12.

6 ) Kinoshita Y, Shiga H, Washiyama K, et al : Thallium transport and the evaluation of olfactory nerve connectivity between the nasal cavity and olfactory bulb. Chem Senses 2008; 33 : 73-8.

7 ) Shiga H, Kinoshita Y, Washiyama K, et al : Odor detection ability and thallium-201 transport in the olfactory nerve of traumatic olfactory-impaired mice. Chem Senses 2008; $33: 633-7$.

8 ) Shiga H, Washiyama K, Hirota K, et al : Use of thallium transport to visualize functional olfactory nerve regeneration in vivo. Rhinology, in press.

9 ) Drobyshevsky A, Robinson AM, Derrick M, et al: Sensory deficits and olfactory system injury detected by novel application of MEMRI in newborn rabbit after antenatal hypoxia-ischemia. Neuro- image 2006 ; 32 : 1106-12.

10) Aschner M, Guilarte TR, Schneider JS, et al: Recent advances in understanding its transport and neurotoxicity. Toxicol Appl Pharmacol 2007 ; 221 : 131-47.

11) Iida $H$, Eberl $S$ : Quantitative assessment of regional myocardial blood flow with thallium-201 and SPECT. J Nucl Cardiol 1998; 5 : 313-31.

12) Higuchi $T$, Taki J, Sumiya $H$, et al : Characterization of cartilaginous tumors with $201 \mathrm{Tl}$ scintigraphy. Ann Nucl Med 2005; 19 : 95-9.

13）広田京子, 志賀英明, 土田明日香, 他：タリウム201経鼻投与における安全性. 日本味と匂誌 2008 ； $15: 527-8$.

14) Sessler MJ, Geck P, Maul FD, et al: New aspects of cellular thallium uptake: $\mathrm{Tl}^{+}-\mathrm{Na}^{+}-2 \mathrm{Cl}^{-}-$cotransport is the central mechanism of ion uptake. Nuklearmedizin 1986 ; 25 : 24-7. 